Hume's Dialogues Concerning Natural Religion (York, 1781). Finally, a copy was acquired of one of the earliest German works on Hume, Friedrich Heinrich Jacobis David Hume uber den Glauben, oder Idealismus und Realismus (Breslau, 1787).

The McGill Hume collection is among the very best in the world, and it continues to grow. The entire collection will be catalogued by mid-1991 and is available to scholars, students and interested persons for consultation in the Department of Rare Books and Special Collections.

\title{
Notes
}

1. Ernest Campbell Mossner, The Life of David Hume (Austin: University of Texas Press, 1954), p. 362 .

2. T.E. Jessop, A Bibliography of David Hume and of Scottish Philosophy From Francis Hutcheson to Lord Balfour (New York: Russell \& Russell, I966).

3. William B. Todd, "David Hume: A preliminary Bibliography," in Hume and the Enlightenment: Essays Presented to Ernest Campbell Mossner, ed. William B. Todd (Edinburgh: Edinburgh University Press, 1974), pp. 192-3.

4. Mossner, pp. 182-6.

\section{Moshe Safdie's Archive}

\author{
by Irena Murray \\ Head, Blackader-Lauterman Library of Architecture and Art
}

\begin{abstract}
A key event in the development of our architecture collections took place in the BlackaderLauterman Library of Architecture and Art last year. In December 1990, after four years of negotiations, architect, author and educator Moshe Safdie, B.Arch. '61, LL.D. (honoris causa) '82, signed an agreement which made the University the sole depository for the extensive archive of his work. When fully constituted, Mr. Safdie's archive will not only include architectural plans, drawings, models, slides, photographs, and office files for all his projects, but also personal sketchbooks, manuscripts of books, correspondence, lectures, films, tapes, diskettes, and other research material, documenting the many aspects of Safdie's work.
\end{abstract}

The Canadian Architecture Collection (CAC) of the Blackader Library will face the challenge of organizing and describing the Safdie projects, to make them accessible to students and researchers. In order to cope with the sheer quantity and variety of material, a series of shipments is being planned by Safdie's principal offices in Boston and Jerusalem. The first shipment, received in February, consisted of two Canadian projects emblematic of Safdie's career: Habitat 67 and the National Gallery of Canada. Close to 150 rolls of architectural drawings and prints, 26 cartons of project files, 7 sketchbooks, as well as small architectural modes of the National Gallery spaces provide a unique insight in the creative process of the author of Beyond Habitat, For Everyone a Garden, Form and Purpose, The Harvard Jerusalem Studio, Beyond Habitat by Twenty Years, and, most recently, Jerusalem: The Future of the Past. 
The Safdie donation is of great significance for many reasons. The archive represents more than twenty-five years of practice, teaching and writing of one of McGill's most famous graduates. The exceptional quantity, variety and richness of material in the archive will provide architecture students, historians and curators with some unique teaching and research opportunities. Canadian projects such as Habitat '67, the National Gallery, the Musée de la Civilisation in Quebec City, the extension to the Musée des Beaux Arts de Montréal, the Ballet Opera House in Toronto, or the Ottawa City Hall will form an important part of our heritage, but they will also be examined in the context of Mr. Safdie's international practice. Mr. Safdie's academic career, which began at McGill in 1970, and included professorships at Yale, Ben Gurion University in Israel, and Harvard, will also be documented in the archive.

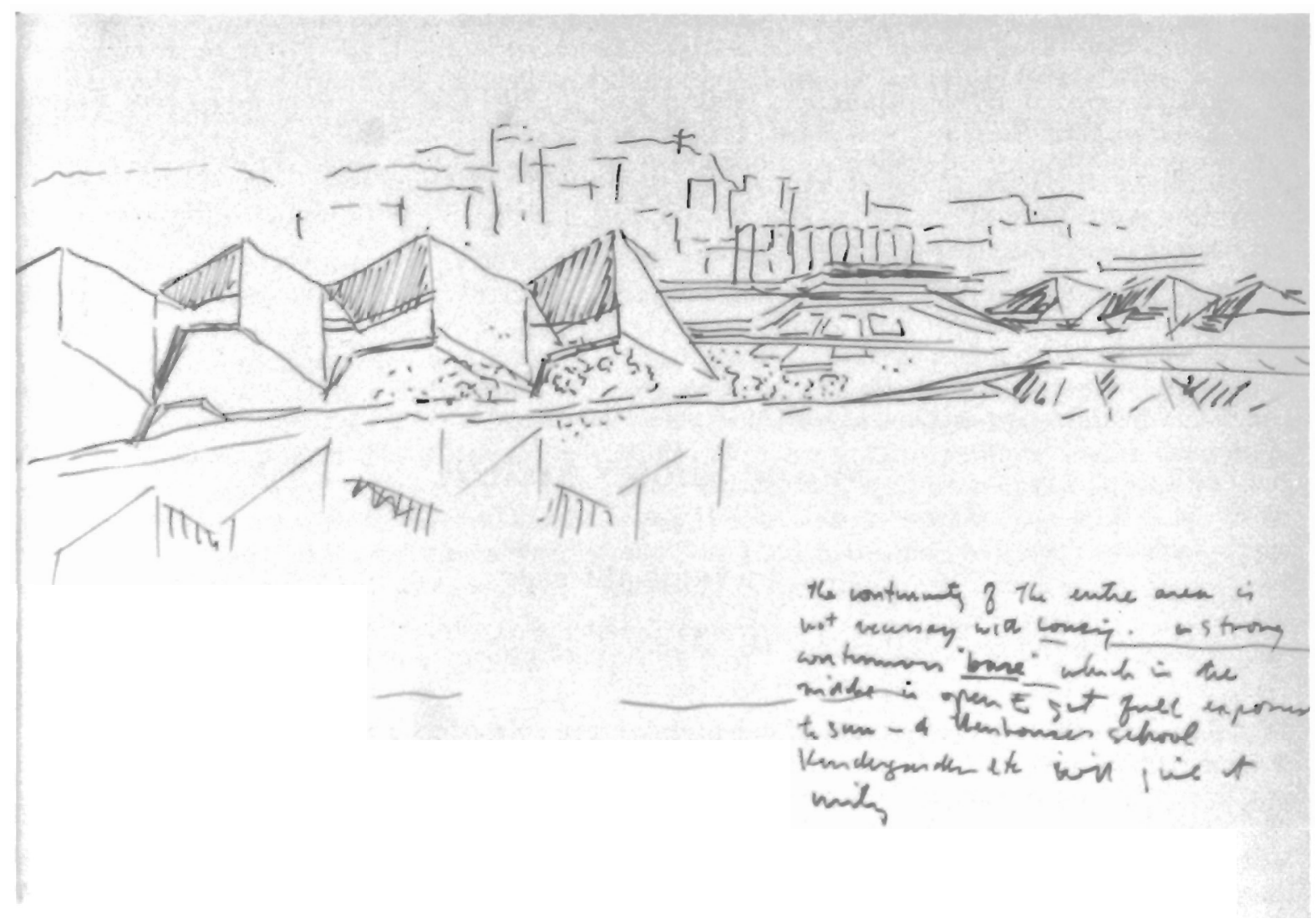

From the beginning, a close relationship has been established between the Canadian Architecture Collection and the office of Moshe Safdie and Associates. The U.S. office has volunteered to make available their inventory sof tware to the library, and its staff is looking for the best way in which diskettes containing the Computer-Assisted Designs (CAD) can be consulted as part of the Safdie archive. The cooperation between the library and the practice will make adding new projects and documentary material easier, as well as enhance our understanding of Safdie's work. 